\title{
EFFECT OF CORE CAPITAL AND SUPPLEMENTARY CAPITAL ON CAPITAL ADEQUACY RATIO (CAR) IN PT. BNI SHARIA PERIOD 2011- 2018
}

\author{
Arjun $^{1}$, Windari ${ }^{2}$, Ali Hardana ${ }^{3}$, Syuaib Nasution ${ }^{4}$ \\ ${ }^{1}$ IAIN Padangsidimpuan (Perbankan Syariah, FEBI, IAIN Padangsidimpuan) \\ ${ }^{2}$ IAIN Padangsidimpuan (Perbankan Syariah, FEBI, IAIN Padangsidimpuan) \\ ${ }^{3}$ IAIN Padangsidimpuan (Ekonomi Syariah, FEBI, IAIN Padangsidimpuan) \\ ${ }^{4}$ IAIN Padangsidimpuan (Ekonomi Syariah, FEBI, IAIN Padangsidimpuan) \\ arjun@gmail.com ${ }^{1}$, wwindariok@gmail.com² ${ }^{2}$ alihardana@iain-padangsidimpuan.ac.id ${ }^{3}$, \\ syuaibnasution@iain-padangsidimpuan.ac.id ${ }^{4}$
}

\begin{abstract}
ABSTRAK
Berdasarkan data yang diperoleh dari laporan keuangan PT. BNI Syariah periode 2011-2018 terjadi peningkatan nilai CAR tidak sejalan dengan peningkatan modal tetapi adanya peningkatan CAR sedangkan modal mengalami penurunan pada tahun 2012, 2016 dan 2018. Penurunan nilai CAR tidak sejalan dengan penurunan modal tetapi adanya penurunan nilai CAR sedangkan modal mengalami peningkatan pada tahun 2017. Tujuan penelitian ini adalah untuk mengetahui pengaruh variabel modal inti dan modal pelengkap secara parsial dan simultan terhadap CAR pada PT. BNI Syariah periode 2011-2018. Hasil penelitian secara parsial (uji t) modal inti tidak memiliki pengaruh secara parsial terhadap CAR yang dibuktikan dengan thitung $<$ ttabel yaitu $(1,296<2,045)$, dan modal pelengkap memiliki pengaruh negatif terhadap CAR yang dibuktikan dengan thitung $>$ ttabel yaitu $(-$ 2,849> -2,045). Sedangkan secara simultan variabel modal inti dan modal pelengkap memiliki pengaruh secara simultan (bersama-sama) terhadap CAR dibuktikan dengan Fhitung $>$ Ftabel yaitu $(4,060>3,33)$.
\end{abstract}

Kata Kunci: Modal Inti, Modal Pelengkap, Capital Adequacy Ratio (CAR)

\begin{abstract}
Based on data obtained from the financial statements of PT. BNI Syariah for the period of 2011-2018 an increase in the value of CAR is not in line with an increase in capital but an increase in CAR while capital has decreased in 2012, 2016 and 2018. A decrease in the value of CAR is not in line with a decrease in capital but a decrease in the value of CAR while capital has increased in 2017. The purpose of this study was to determine the effect of core capital and complementary capital variables partially and simultaneously on CAR at PT. BNI Syariah for the period of 2011-2018. The results of the partial research ( $t$ test) core capital has no partial effect on CAR as evidenced by tcount <ttable $(1,296$ $<2,045)$, and supplementary capital has a negative effect on CAR as evidenced by tcount $>$ ttable ie ($2,849>-2,045)$. Whereas simultaneously core capital and supplementary capital variables have simultaneous (joint) influence on CAR as evidenced by Fcount $>$ Ftable $(4.060>3.33)$.
\end{abstract}

Keywords: Core Capital, Complementary Capital, Capital Adequacy Ratio (CAR) 



\section{Journal of Sharia Banking}

\section{A. PENDAHULUAN}

Kinerja manajemen bank dalam mengelola permodalan dapat dilihat melalui rasio keuangan yang salah satu diantaranya adalah Capital Adequacy Ratio (CAR) yang merupakan indikator terhadap kemampuan bank untuk mengcover atau menutupi penurunan aktivanya sebagai akibat dari kerugian-kerugian bank yang disebabkan oleh aktiva produktif yang berisiko. Besarnya CAR yang dipersyaratkan oleh Bank Indonesia untuk bank-bank yang beroperasi di Indonesia adalah sebesar minimum 8\% (Muhammad, 2015:107). Besar kecilnya CAR yang dimiliki oleh sebuah bank akan dipengaruhi oleh kinerja aspek keuangan lainnya yaitu aspek likuiditas, aspek kualitas aktiva, aspek sensitivitas terhadap pasar, dan aspek profitabilitas.

Kinerja bank yang menurun akan mempengaruhi kepercayaan masyarakat karena pada dasarnya bank merupakan indusri yang dalam menjalankan usahanya memerlukan kepercayaan masyarakat sehingga kesehatan bank perlu diperhatikan. Penilaian terhadap rasio permodalan yang lazim digunakan untuk mengukur kesehatan bank yaitu CAR yang didasarkan pada rasio modal terhadap Aktiva Tertimbang Menurut Risiko (ATMR). Sejak periode krisis sampai saat ini CAR menjadi acuan utama dalam menentukan kesehatan bank, dimulai dari minimum sebesar $4 \%$ pada periode awal terjadinya krisis, persyaratan besaran minimum CAR telah ditingkatkan secara bertahap dan sejak awal tahun 2001, Bank Indonesia menetapkan CAR sebesar 8\% yang ditentukan oleh BIS (Bank for International Setlement). Ketentuan diadopsi oleh Bank Indonesia dan menerapkan ketentuan ini melalui PBI menjadi KPMM (Kewajiban Pemenuhan Modal Minimum).

CAR merupakan indikator terhadap kemampuan bank untuk menutupi penurunan aktivanya sebagai akibat dari kerugian-kerugian bank yang disebabkan oleh aktiva berisiko. CAR adalah rasio yang memperlihatkan seberapa jauh seluruh aktiva bank yang mengandung risiko (kredit, penyertaan, surat berharga, tagihan pada bank lain) ikut di biayai dari dana modal sendiri bank disamping memperoleh dana dari sumber di luar bank, seperti dana dari masyarakat, pinjaman, dan lain-lain (Dendawijaya, 2003:122).

Berikut ini tabel perkembangan persentase CAR, jumlah modal inti dan jumlah modal pelengkap pada PT. BNI Syariah periode 2011-2018 :

Tabel 1

Perkembangan Persentase CAR, Jumlah Modal Inti dan Modal Pelengkap pada PT. BNI Syariah periode 2011-2018

\begin{tabular}{|c|c|c|c|}
\hline Tahun & $\begin{array}{c}\text { CAR } \\
\text { (\%) }\end{array}$ & $\begin{array}{c}\text { Modal Inti } \\
\text { (Jutaan } \\
\text { Rupiah) }\end{array}$ & $\begin{array}{c}\text { Modal } \\
\text { Pelengkap } \\
\text { (Jutaan Rupiah) }\end{array}$ \\
\hline 2011 & 20,67 & 1.049 .092 & 52.027 \\
\hline 2012 & 14,10 & 1.112 .982 & 75.036 \\
\hline 2013 & 16,23 & 1.262 .206 & 103.190 \\
\hline 2014 & 18,42 & 1.868 .375 & 135.983 \\
\hline 2015 & 15,48 & 2.064 .262 & 89.919 \\
\hline
\end{tabular}




\begin{tabular}{|c|c|c|c|}
\hline 2016 & 14,92 & 2.428 .140 & 154.458 \\
\hline 2017 & 20,14 & 3.729 .820 & 84.279 \\
\hline 2018 & 19,31 & 4.153 .222 & 134.594 \\
\hline
\end{tabular}

Sumber: www.bnisyariah.co.id (data diolah)

Berdasarkan tabel 1 di atas CAR mengalami fluktuasi dari tahun 2011 sampai dengan tahun 2018. Pada tahun 2012 CAR mengalami penurunan yang paling tinggi sebesar 6,57 persen. Pada tahun 2013 CAR mengalami peningkatan sebesar 2,13 persen. Pada tahun 2014 CAR mengalami peningkatan juga sebesar 2,19 persen. Pada tahun 2015 CAR mengalami penurunan kembali sebesar 2,94 persen. Pada tahun 2016 CAR mengalami penurunan sebesar 0,56 persen. Pada tahun 2017 CAR mengalami peningkatan yang paling tinggi sebesar 5,22 persen. Sedangkan pada tahun 2018 mengalami penurunan sebesar 0,83 persen.

Pada modal inti, modal inti meningkatkan dari tahun 2011 sampai dengan tahun 2018. Pada tahun 2012 modal inti mengalami peningkatan sebesar 63.890.000.000 rupiah. Pada tahun 2013 sebesar 149.224.000.000 rupiah. Pada tahun 2014 sebesar 606.169.000.000 rupiah. Pada tahun 2015 sebesar 195.887.000.000 rupiah. Pada tahun 2016 sebesar 363.878 .000 .000 rupiah. Pada tahun 2017 mengalami peningkatan paling tinggi sebesar 1.301.680.000.000 rupiah. Sedangkan pada tahun 2018 sebesar 423.402.000.000 rupiah.

Pada modal pelengkap, modal pelengkap fluktuasi dari tahun 2011 sampai dengan tahun 2018. Pada tahun 2012 modal
POINT Vol. 2, No. 1, Jul 2021 pelengkap mengalami peningkatan sebesar 23.209.000.000 rupiah. Pada tahun 2013 modal pelengkap mengalami peningkatan juga sebesar 28.154.000.000 rupiah. Pada tahun 2014 modal pelengkap kembali mengalami peningkatan sebesar 32.793.000.000 rupiah. Pada tahun 2015 modal pelengkap mengalami penurunan sebesar 46.064.000.000 rupiah. Pada tahun 2016 modal pelengkap mengalami peningkatan yang paling tinggi sebesar 64.539 .000 .000 rupiah. Pada tahun 2017 modal pelengkap mengalami penurunan kembali dan merupakan penurunan yang paling tinggi sebesar 70.179.000.000 rupiah. Sedangkan pada tahun 2018 modal pelengkap mengalami peningkatan sebesar 50.315.000.000 rupiah.

Berdasarkan data laporan keuangan PT. BNI Syariah periode 2011-2018 dapat dilihat bahwa beberapa fenomena yang terjadi. Fenomena yang pertama, pada tahun 2012 nilai CAR mengalami penurunan sedangkan jumlah modal inti dan pelengkap meningkat begitu juga yang terjadi pada tahun 2016 dan 2018. Fenomena kedua, pada tahun 2015 nilai CAR mengalami peningkatan sedangkan modal pelengkap mengalami penurunan begitu juga yang terjadi pada tahun 2017.

Fenomena-fenomena yang terjadi pada PT. BNI Syariah periode 2011-2018 bertentangan dengan kesepakatan BIS tentang ketentuan permodalan pada tahun 1988, dengan menetapkan CAR, yaitu rasio minimum yang mendasarkan kepada perbandingan 
antara modal dan aktiva beresiko, secara sistematis (Khaerul Umam, 2013:251) :

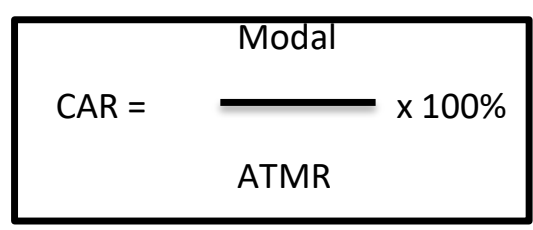

Berdasarkan teori dan rumus di atas dapat disimpulkan bahwa jika jumlah modal mengalami peningkatan maka nilai CAR akan meningkat juga dan jika modal mengalami penurunan maka nilai CAR akan menurun juga. Dari fenomena yang ditemukan oleh peneliti bahwa adanya peningkatan nilai CAR tetapi modal mengalami penurunan dan adanya penurunan nilai CAR tetapi modal mengalami peningkatan.

Berdasarkan tabel di atas, pada tahun 2014 total pendapatan Bank Rakyat Indonesia Syariah sebesar Rp. 2.056.602.000 pada tahun 2015 terjadi peningkatan sebesar Rp. 368.150.000 dan CSR pada tahun 2014 sebesar Rp. 2.714.000 pada tahun 2015 terjadi penurunan sebesar Rp. 1.340.000. Pada tahun 2016 total pendapatan Bank Mega Syariah sebesar Rp. 660.473.000.000 pada tahun 2017 terjadi penurunan sebesar Rp. 21.576.000.000 dan CSR pada tahun 2016 sebesar 394.000.000 pada tahun 2017 terjadi peningkatan sebesar Rp. 266.000.000. Akan tetapi pada tahun 2015 total pendapatan Bank Panin Syariah sebesar Rp. 711.206.000.000 terjadi penurunan kembali pada tahun 2016 sebesar Rp. 18.073.000.000 dan CSR pada tahun 2015 sebesar Rp.
281.000.000 terjadi peningkatan pada tahun 2016 sebesar Rp. 359.000.000.

\section{B. METODE}

Penelitian ini dilakukan di PT. BNI Syariah seluruh Indonesia melalui situs resmi PT. BNI Syariah (www.bnisyariah.co.id). Penelitian ini adalah penelitian kuantitatif, sumber data dalam penelitian ini adalah data sekunder dengan bentuk data time series sebanyak 32 sampel. teknik pengumpulan data adalah dokumentasi yang ada di situs resmi www.bnisyariah.co.id pada laporan keuangan PT. BNI Syariah Periode 2011-2018. Teknik analisis data dengan uji statistik deskriptif, uji asumsi klasik, uji hipotesis dan analisis regresi linier berganda, dengan pengolahan data Berdasarkan hasil penelitian menunjukkan hasil thitung untuk variabel independen modal inti adalah sebesar 1,296 dan nilai ttabel dengan nilai signifikansi $\alpha=0,05$ dan $\mathrm{df}=(\mathrm{n}-\mathrm{k}-1), \mathrm{df}=$ $(32-2-1)=29$ jadi nilai ttabel adalah sebesar 2,045. Maka dapat ditarik kesimpulan bahwa nilai thitung $<$ ttabel $=(1,296<2,048)$ digunakan melalui program SPSS 23.

Persamaan regresi linear berganda dapat dituliskan sebagai berikut:

$$
C A R=\beta 0+\beta 1 M I+\beta 2 M P+e
$$

Penjelasan :

$$
\begin{array}{ll}
\text { CAR } & =\text { Capital Adequacy Ratio } \\
\beta 0 & =\text { intercept } / \text { konstan } \\
\mathrm{MI} & =\text { Modal Inti } \\
\mathrm{MP} & =\text { Modal Pelengkap } \\
\beta 1, \beta 2 & =\text { Koefisien regresi } \\
\mathrm{e} & =\text { Tingkat Kesalahan (Term of Error) }
\end{array}
$$


Analisis regresi berganda digunakan untuk mengetahui keeratan hubungan antara variabel dependent (laba) dengan faktor-faktor yang mempengaruhinya atau variabel independent (Fee Based Income dan biaya operasional).

\section{HASIL DAN PEMBAHASAN}

Berdasarkan hasil penelitian menunjukkan hasil $t_{\text {hitung }}$ untuk variabel independen modal inti adalah sebesar 1,296 dan nilai $t_{\text {tabel }}$ dengan nilai signifikansi $\alpha=0,05$ dan df $=(n-k-1), d f=(32-2-1)=29$ jadi nilai ttabel adalah sebesar 2,045. Maka dapat ditarik kesimpulan bahwa nilai $t_{\text {hitung }}<t_{\text {tabel }}=(1,296<$ $2,048)$.

Berdasarkan hasil penelitian menunjukkan hasil $t_{\text {hitung }}$ untuk variabel independen modal pelengkap adalah sebesar 2,849 nilai ttabel dengan nilai signifikansi $\alpha=$ 0,05 dan $d f=(n-k-1), d f=(32-2-1)=29$ jadi nilai ttabel adalah sebesar 2,045. Maka dapat ditarik kesimpulan bahwa nilai $t_{\text {hitung }}>t_{\text {tabel }}=(-2,849>-$ 2,045). Sehingga HO ditolak dan Ha diterima artinya modal pelengkap berpengaruh terhadap CAR.

Berdasarkan hasil penelitian, nilai $\mathrm{F}_{\text {hitung }}$ adalah sebesar 4,060. Maka dapat disimpulkan bahwa $F_{\text {hitung }}>F_{\text {tabel }}=4,060>3,33$, artinya $\mathrm{HO}$ ditolak dan Ha diterima.

Dapat dilihat dari hasil uji regresi linear berganda, maka persamaan dalam penelitian ini adalah:

$$
C A R=\beta 0+\beta 1 M I+\beta 2 M P+e
$$

POINT Vol. 2, No. 1, Jul 2021

$\mathrm{CAR}=20,494+6,741 \mathrm{Ml}-4,576 \mathrm{MP}$

Dimana:

CAR = Capital Adequacy Ratio

MI = Modal Inti

$\mathrm{MP} \quad=$ Modal Pelengkap

Penjelasan dari persamaan di atas adalah sebagai berikut:

a. Nilai konstanta ( $\beta 0$ ) adalah 20,494 , artinya jika modal inti dan modal pelengkap nilainya 0 maka CAR sebesar 20,494 persen.

b. Nilai koefisien regresi variabel modal inti $(\beta 1)$ adalah sebesar 6,741 artinya bahwa setiap peningkatan MI sebesar Rp.1.000.000, maka akan meningkatkan CAR sebesar 6,741 persen dengan asumsi variabel lain nilainya tetap.

c. Nilai koefisien regresi variabel modal pelengkap ( $\beta 2$ ) adalah sebesar $-4,576$ artinya bahwa setiap peningkatan MP sebesar Rp.1.000.000, maka akan menurunkan harga saham sebesar 4,576 persen dengan asumsi variabel lain nilainya tetap.

\section{PENUTUP}

\section{Kesimpulan}

Berdasarkan hasil pengolahan data dari penelitian yang berjudul "Pengaruh Modal Inti dan Modal Pelengkap terhadap Capital Adequacy Ratio (CAR) pada PT. BNI Syariah Periode tahun 2011-2018" peneliti mengambil kesimpulan sebagai berikut :

1. Tidak terdapat pengaruh modal inti secara parsial terhadap Capital Adequacy Ratio 
(CAR) pada PT. BNI Syariah periode 20112018, dibuktikan dengan hasil penelitian $t_{\text {hitung }}<t_{\text {tabel }}=(1,296<2,045)$ sehingga $\mathrm{HO}$ diterima dan Ha ditolak artinya modal inti tidak berpengaruh terhadap CAR.

2. Terdapat pengaruh modal pelengkap secara parsial terhadap Capital Adequacy Ratio (CAR) pada PT. BNI Syariah periode 20112018, dibuktikan dengan hasil penelitian $t_{\text {hitung }}>t_{\text {tabel }}=(-2,849<-2,045)$ sehingga $\mathrm{HO}$ ditolak dan $\mathrm{Ha}$ diterima artinya modal pelengkap berpengaruh negatif terhadap CAR.

3. Terdapat pengaruh modal inti dan modal pelengkap secara simultan terhadap Capital Adequacy Ratio (CAR) pada PT. BNI Syariah periode 2011-2018, dibuktikan dengan hasil penelitian nilai $F_{\text {hitung }}>F_{\text {tabel }}=(4,060>3,33)$ artinya $\mathrm{HO}$ ditolak dan $\mathrm{Ha}$ diterima.

\section{Saran}

Semoga adanya peningkatan CAR perbankan syariah ke depannya.

\section{DAFTAR PUSTAKA}

Abdurahmat Fathoni, Metodologi Penelitian dan Teknik Penyusunan Skripsi, Jakarta: PT. Gramedia Pustaka Utama, 2017.

Dendawijaya, Manajemen Perbankan, Jakarta: Ghalia Indonesia, 2003.

Departemen Keagamaan, Al-Qur'an dan Terjemahannya, Bandung: Syamil Qur'an, 2012.
Duwi Priyatno, SPSS 22 Pengolahan Data Terpraktis, Yogyakarta: CV. Andi Offset, 2014.

https//:tafsirq.com

Husein Umar, Metode Penelitian untuk Skripsi, Jakarta: PT. RAJA GRAFINDO PERSADA, 2013.

Imam Ghozali, Aplikasi Analisis Multivariete Program IBM SPSS 23, Semarang: Badan Penerbit Universitas Diponegoro, 2013.

Jerry Andreas Hengkeng, Een N. Walewangko, dan Audie O.Niode, Analisis FaktorFaktor Yang Mempengaruhi Capital Adequacy Ratio Bank Sulut-Go Tahun 2002.I - 2017.IV, Jurnal: Fakultas Ekonomi dan Bisnis, Universitas Sam Ratulangi Manado, Vol. 18, No. 04, 2018.

Kasmir, Bank dan Lembaga Keuangan Lainnya. Edisi Revisi 2002, Jakarta: PT. RAJA GRAFINDO PERSADA, 2002.

, Manajemen Perbankan Jakarta: PT. RAJAGRAFINDO PERSADA, 2014.

Khaerul Umam, Manajemen Perbankan Syariah, Bandung: CV. PUSTAKA SETIA, 2013.

Muhammad, Manajemen Dana Bank Syariah, Yogyakarta: EKONISIA, 2015.

Mudrajad Kuncoro, Metodologi Riset Untuk Bisnis dan Ekonomi, ed3, Jakarta: Erlangga, 2009.

Nur Asnawi dan Masyhuri, Metodologi Riset Manajemen Pemasaran, Malang: UINMALIKI Press, 2011. 
Sugioyono, Metode Penelitian Kuantitatif, kualitatif, dan R\&D, Bandung: Alfabeta, 2016.

Taswan, Manajemen Perbankan : Konsep, Teknik \& Aplikasi, Yogyakarta: UPP STIM YKPN YOGYAKARTA, 2010

Yansen, Faktor-faktor yang Mempengaruhi CAR, Tesis: Universitas Diponegoro Semarang, 2008.
POINT Vol. 2, No. 1, Jul 2021

www.bi.go.id

www.economy.okezone.com

www.jonathansarwono.info

www.kompasiana.com

www.spssindonesia.com 